\title{
Optimization of the Lactococcus lactis nisin-controlled gene expression system NICE for industrial applications Igor Mierau*1, Kees Olieman ${ }^{1}$, James Mond ${ }^{2}$ and Eddy J Smid ${ }^{1}$
}

Address: ${ }^{1}$ NIZO food research, P.O. Box 20, 6710 BA EDE, The Netherlands and 2Biosynexus Inc., 9119 Gaither Road, Gaithersburg, MD 20877, USA

Email: Igor Mierau* - igor.mierau@nizo.nl; Kees Olieman - kees.olieman@nizo.nl; James Mond - jimmymond@biosynexus.nl; Eddy J Smid - eddy.smid@nizo.nl

* Corresponding author

Published: 30 May 2005

Microbial Cell Factories 2005, 4:16 doi:10.1 186/1475-2859-4-16
Received: 18 April 2005

Accepted: 30 May 2005

This article is available from: http://www.microbialcellfactories.com/content/4/1/16

(C) 2005 Mierau et al; licensee BioMed Central Ltd.

This is an Open Access article distributed under the terms of the Creative Commons Attribution License (http://creativecommons.org/licenses/by/2.0), which permits unrestricted use, distribution, and reproduction in any medium, provided the original work is properly cited.

\begin{abstract}
Background: The nisin-controlled gene expression system NICE of Lactococcus lactis is one of the most widely used expression systems in Gram-positive bacteria. Despite its widespread use, no optimization of the culture conditions and nisin induction has been carried out to obtain maximum yields. As a model system induced production of lysostaphin, an antibacterial protein (mainly against Staphylococcus aureus) produced by S. simulans biovar. Staphylolyticus, was used. Three main areas need optimization for maximum yields: cell density, nisin-controlled induction and protein production, and parameters specific for the target-protein.
\end{abstract}

Results: In a series of $\mathrm{pH}$-controlled fermentations the following parameters were optimized: $\mathrm{pH}$ of the culture, use of $\mathrm{NaOH}$ or $\mathrm{NH}_{4} \mathrm{OH}$ as neutralizing agent, the addition of zinc and phosphate, the fermentation temperature, the time point of induction (cell density of the culture), the amount of nisin added for induction and the amount of three basic medium components, i.e. yeast extract, peptone and lactose. For each culture growth and lysostaphin production was followed. Lysostaphin production yields depended on all parameters that were varied. In the course of the optimization a three-fold increase in lysostaphin yield was achieved from $100 \mathrm{mg} / \mathrm{l}$ to $300 \mathrm{mg} / \mathrm{l}$.

Conclusion: Protein production with the NICE gene expression system in L. lactis strongly depends on the medium composition, the fermentation parameters and the amount of nisin added for induction. Careful optimization of key parameters lead to a significant increase in the yield of the target protein.

\section{Background}

Lactococcus lactis is a Gram-positive lactic acid bacterium that is widely used in food fermentations, such as in cheese and butter production. In the last two decades the physiology and genetics of this bacterium have been thoroughly studied $[1,2]$. At present the genome sequences of several strains of $L$. lactis have been elucidated, leading to an acceleration and integration of our knowledge of these bacteria [3-6]. Because of its genetic accessibility and because it is easy to handle, L. lactis, in addition to its traditional applications, has been extensively developed and used for the expression of heterologous genes, and has become one of the most used Gram-positive gene expression hosts. Table 1 gives an overview of the wide range of applications that involve L. lactis as host bacterium. 
Table I: Overview of various applications of the NICE system

\begin{tabular}{|c|c|c|}
\hline Application area & Application & Reference \\
\hline \multirow[t]{4}{*}{ Expression of homologous genes } & Aminopeptidase $\mathrm{N}$ & {$[7]$} \\
\hline & ATPase system (8 gene operon) & {$[28]$} \\
\hline & Aminoacylase & {$[29]$} \\
\hline & Cluster of genes encoding folate biosynthesis & {$[19]$} \\
\hline \multirow[t]{4}{*}{ Expression of heterologous genes of $\mathrm{Gram}^{+}$and $\mathrm{Gram}^{-}$bacteria } & NADH oxidase of Streptococcus mutans & {$[30]$} \\
\hline & Fructose bisphosphatase of Escherichia coli & {$[31]$} \\
\hline & Green fluorescent protein of Aequoria victoria & {$[32]$} \\
\hline & Lysostaphin of Staphylococcus simulans biovar. Staphylolyticus & {$[15]$} \\
\hline \multirow[t]{2}{*}{ Protein secretion } & Lipase of Staphylococcus hyicus & {$[33]$} \\
\hline & Bovine beta-lactoglobulin & {$[34]$} \\
\hline \multirow[t]{5}{*}{ Membrane proteins: prokaryotic and eukaryotic } & Multidrug transporter of Lactococcus lactis & \\
\hline & Xylidose transporter of Lactobacillus pentosus & \\
\hline & ATP/ADP translocator of Rickettsia prowazekii & Review [35] \\
\hline & KDEL receptor of Homo sapiens & \\
\hline & Mitochondrial carriers of Saccharomyces cerevisiae & \\
\hline \multirow[t]{3}{*}{ Cloning of toxic genes } & Lysis cassette of the virulent phage us 3 of & {$[26]$} \\
\hline & Lactococcus lactis & \\
\hline & Autolysin gene of Leuconostoc citreum & {$[36]$} \\
\hline \multirow[t]{2}{*}{ Bacterial antigens } & Antigen L7/I2 of Brucella abortus & {$[13,37]$} \\
\hline & C subunit of tetanus toxin (TTFC) of Clostridium tetani & [38] \\
\hline Viral antigens & Non-structural protein 4 of bovine rotavirus & {$[13,39]$} \\
\hline Cytokines & Interleukin 12 of Homo sapiens & {$[40]$} \\
\hline Industrial-scale application & Lysostaphin of Staphylococcus simulans biovar. Staphylolyticus & {$[15]$} \\
\hline
\end{tabular}

Regulated gene expression can be of critical importance in achieving high yields of proteins. This is either important for the expression of genes that form toxic products for the cell (see Table 1) or for the conservation of energy for producing biomass prior to directed overproduction of the protein of interest. The most commonly used regulated expression system of Gram positive bacteria is the NIsin Controlled gene Expression system NICE of L. lactis [7]. Sub-toxic amounts of nisin in the $\mathrm{ng} / \mathrm{mL}$ range are sufficient to fully activate the otherwise tightly closed promoter [8]. In the natural situation nisin binds to the receptor NisK. Subsequently NisK activates NisR by phosphorylation and the activated NisR induces the nisin operon at the nisin A promoter [9]. To exploit this system for gene expression, the genes of the receptor protein and the response regulator - nisK and nisR - have been isolated and placed on the chromosome of a suitable host strain. Furthermore, the nisin A promoter has been isolated and placed on a plasmid. When a gene is cloned down-stream of this promoter and the construct is placed in a nisRK strain, expression can be activated by the addition of nisin (Figure 1) [7]. Depending on the presence of a signal sequence the product is either accumulated inside the cell or secreted into the medium (see Table 1).

Escherichia coli is, at present, the dominant prokaryotic system for industrial gene expression. This is due to high yields, ease in genetic handling, long-term experience and extensive documentation with the US Food and Drug Administration and other regulatory bodies. However, there are also various disadvantages, such as the formation of endotoxins, the formation of inclusion bodies, the presence of two membranes, which hampers secretion, and the relatively complicated aerobic fermentation $[10,11]$. L. lactis, on the other hand, has a number of properties that make this bacterium an interesting alternative candidate for large-scale gene expression: the bacterium is food grade (used in food production for thousands of years), it is used at very large scales, and plasmid selection mechanisms are available that are food grade and selfcloning (e.g. growth on lactose) [12]. Furthermore, no endotoxins or inclusion bodies are formed and sophisticated genetic tools enable easy genetic handling $[13,14]$. Finally, simple, non-aerated fermentation makes direct scale-up from 1-L scale to 1000-L scale possible $[2,14]$. Recently, we have demonstrated in our laboratory that nisin controlled gene expression can be effectively used in 3000-L scale fermentations [15].

The NICE system has been used in a multitude of laboratory applications (Table 1), in which gene expression is often performed in acidifying cultures. The drawback of this culture type is its low final cell density due to medium acidification by lactic acid. pH-controlled fermentations, 


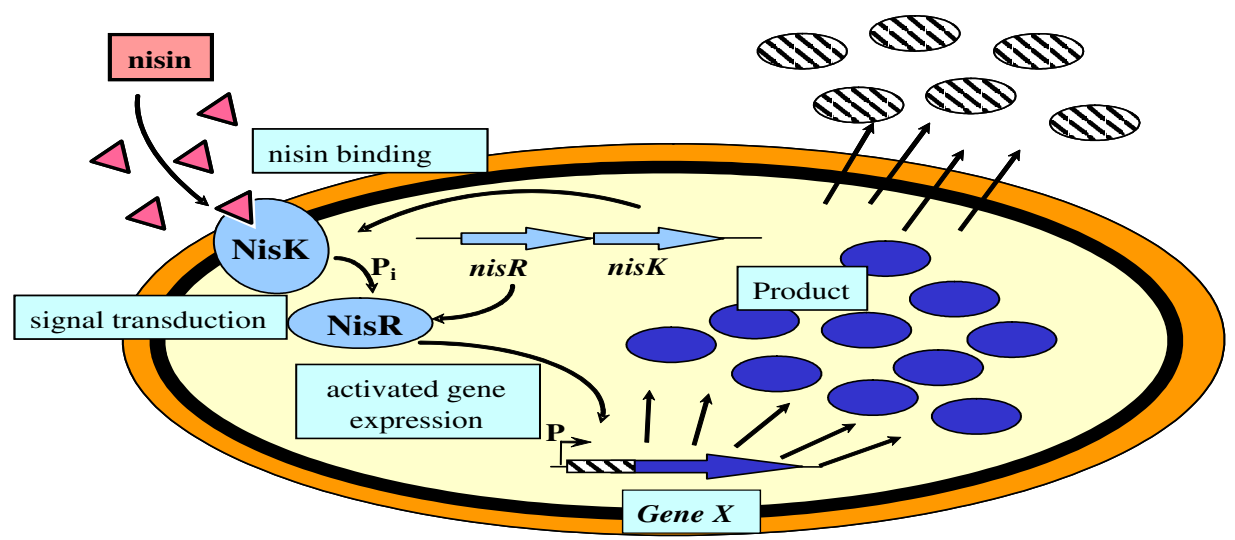

Figure I

Schematic overview of the NICE system, its components and its function. NisK and NisR are the sensor protein and the response regulator, respectively. The product of the expressed gene can either accumulate in the cell or be secreted into the extracellular medium depending on the presence of a signal sequence in the construct.

on the other hand, result in at least five-fold higher cell densities and thus higher biomass yields. However, no systematic optimization of the induction and expression of the NICE system under pH-regulated conditions has yet been performed. Three main areas need optimization for maximum yields: cell density of the culture, nisin-controlled induction and protein production, and parameters specific for the target-protein.

Lysostaphin is a $25 \mathrm{kD}$ antibacterial protein produced by Staphylococcus simulans biovar. Staphylolyticus [16] and mainly used against multiple antibiotic resistant $S$. aureus $[17,18]$. In this paper we demonstrate, with lysostaphin as a model, that careful optimization of key parameters of the induction and production process can lead to an at least three-fold increase of the fermentation yield from $100 \mathrm{mg} / \mathrm{L}$ to $300 \mathrm{mg} / \mathrm{L}$ lysostaphin.

\section{Results}

\section{Introduction}

At present, protocols for nisin-induced gene expression only exist for acidifying batch cultures (see e.g. $[7,19]$ ) but not for pH-controlled batch cultures. Therefore, a protocol that was previously developed at our laboratory for large-scale lysostaphin production [15] was used as a starting point. The cultivation and induction conditions were as follows: $\mathrm{pH}$ controlled (using $\mathrm{NaOH}$ ) growth at $\mathrm{pH} 6.5$, growth temperature $30^{\circ} \mathrm{C}$, inoculum $1 \%$, induction at $\mathrm{OD}_{600}=1(=0.3 \mathrm{~g} / \mathrm{L}$ cell dry weight [20] $)$ with 10 $\mathrm{ng} / \mathrm{mL}$ nisin, and harvest after $6 \mathrm{~h}$. The initial medium composition was: $5 \%$ lactose, $1.5 \%$ soy peptone, $1 \%$ yeast extract, $1 \mathrm{mM} \mathrm{MgSO}_{4}$ and $0.1 \mathrm{mM} \mathrm{MnSO}_{4}$.

In a series of 58 1-L fermentations the following parameters were tested and optimized: $\mathrm{pH}$, neutralization agent, addition of phosphate and zinc, fermentation temperature, the time point of induction, i.e. cell density, the concentration of peptone, yeast extract and lactose in the medium and the lysostaphin production time after induction. 


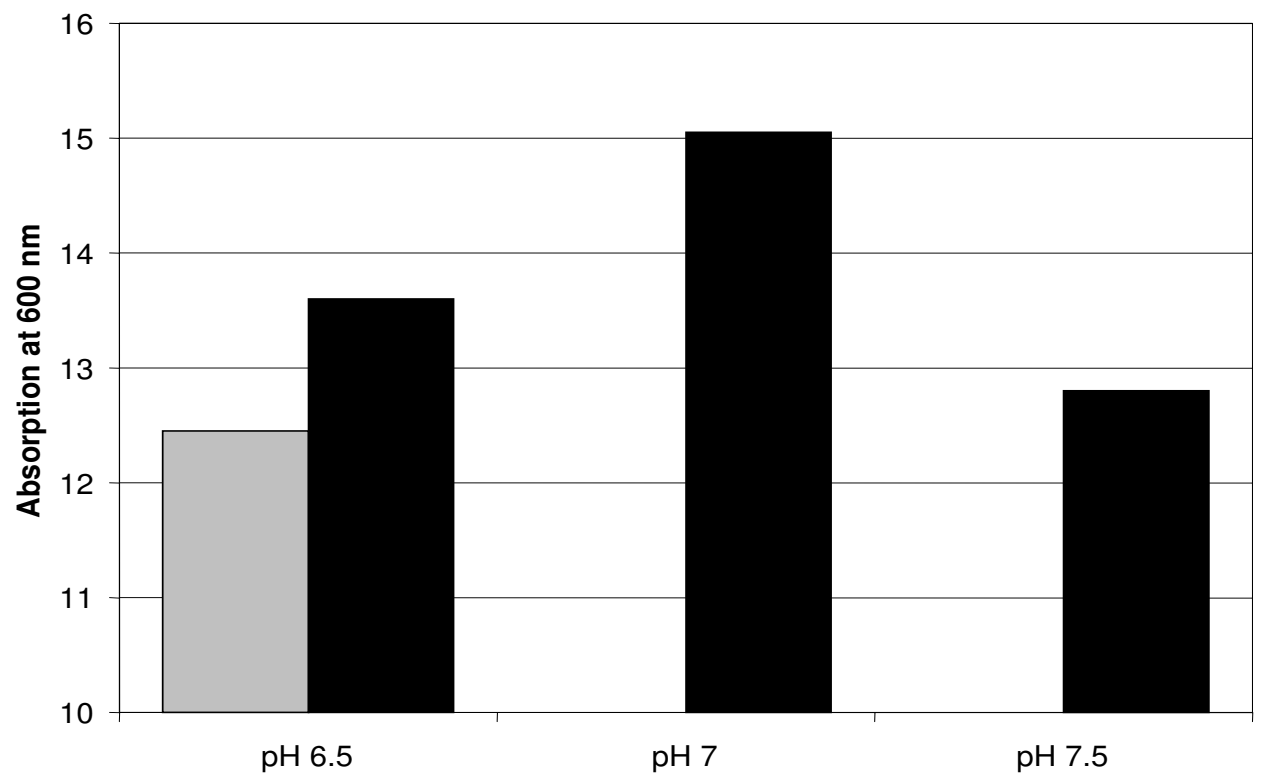

Figure 2

Biomass production depending on $\mathrm{pH}$ and neutralizing agent. The grey bar indicates the use of $\mathrm{NaOH}$ for neutralization of the culture and black bars indicate the use of $\mathrm{NH}_{4} \mathrm{OH}$ for neutralization. Biomass production is expressed in optical density at $600 \mathrm{~nm}$ (path length $=1 \mathrm{~cm}$ ) (the dry cell weight factor is $0.3 \mathrm{~g} / \mathrm{L} / / \mathrm{OD}_{600}$ ). Higher biomass production may be beneficial for higher yield of the produced heterologous protein.

\section{pH and neutralizing agent}

The main fermentation end product of L. lactis is lactate, which is toxic and retards growth above a certain concentration. The toxic effect of lactate depends on its undissociated form [21]. Therefore, any increase of the $\mathrm{pH}$ can lead to a prolongation of growth in the presence of higher concentrations of lactate. $\mathrm{NaOH}$ is a more alkaline neutralizing agent than $\mathrm{NH}_{4} \mathrm{OH}$ and could cause cell damage. Furthermore, $\mathrm{NH}_{4} \mathrm{OH}$ could contribute to the ammonium metabolism of the cell [22]. Figure 2 shows that neutralization with $\mathrm{NH}_{4} \mathrm{OH}$ has a small effect, however the combination of $\mathrm{NH}_{4} \mathrm{OH}$ with an increase of the fermentation $\mathrm{pH}$ to 7.0 leads to prolonged exponential growth (not shown) and to a higher final cell density. Increase of the $\mathrm{pH}$ to 7.5 leads to a retardation of the growth rate and has therefore not been further pursued.

\section{Addition of phosphate and zinc}

$0.01 \%$ of sodium phosphate $\left(\mathrm{Na}_{2} \mathrm{HPO}_{4} * 2 \mathrm{H}_{2} \mathrm{O}\right)$ was added to evaluate the effect on growth performance. Furthermore, zinc was specifically added, because lysostaphin is a metallo-enzyme with zinc as co-factor [16]. Elemental analysis of the basic medium had shown that it contained $1.2 \mathrm{mg} / \mathrm{L} \mathrm{Zn}^{2+}$. This amount would be sufficient for a maximum of $500 \mathrm{mg} / \mathrm{L}$ lysostaphin if all the zinc were available. Therefore, $100 \mu \mathrm{M}(16 \mathrm{mg} / \mathrm{L}) \mathrm{ZnSO}_{4}$ was added, which would allow the production of a maximum of $2.5 \mathrm{~g} / \mathrm{L}$ active lysostaphin. Addition of these components had no significant effect on growth under the initial fermentation and induction conditions (Figure 3). However, in a later stage when induction was performed at a higher cell density and with more nisin (induction at $\mathrm{OD}_{600}=5$ with $40 \mathrm{ng} / \mathrm{ml}$ nisin) considerably less 


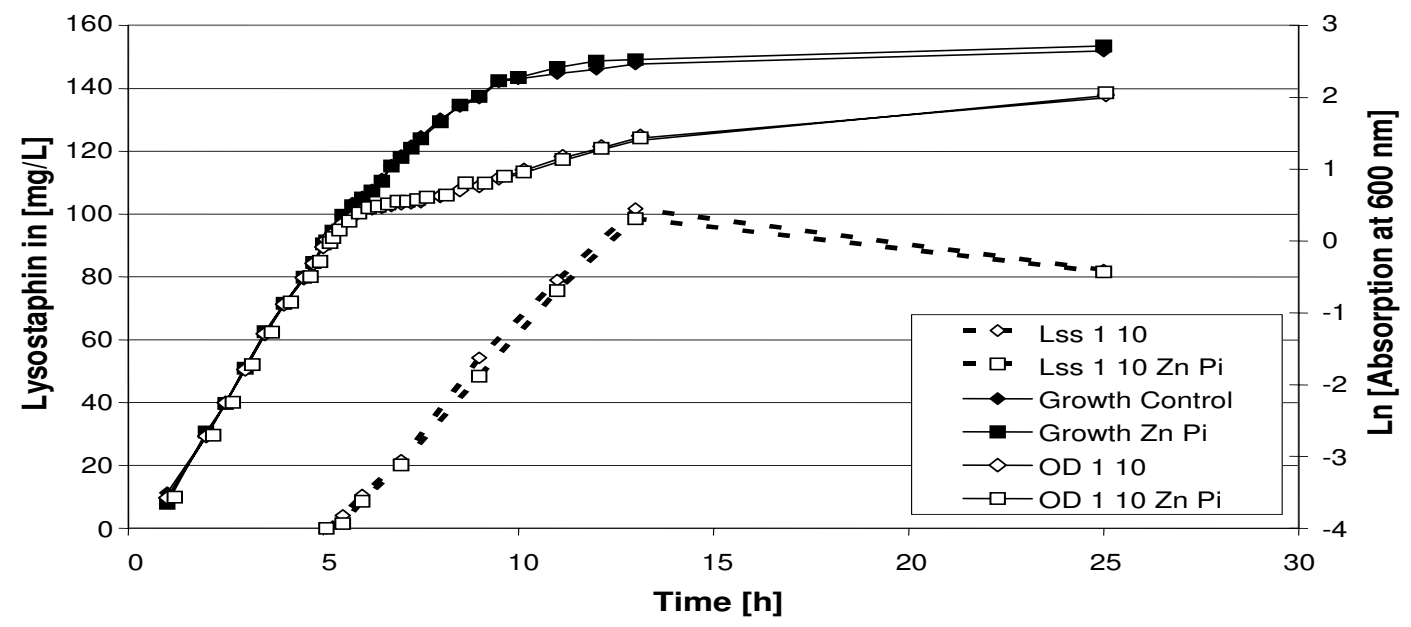

Figure 3

Influence of zinc and phosphorus $\left(Z n P_{i}\right)$ on growth, induction and lysostaphin production. Growth of the culture is indicated with continuous lines. Production of lysostaphin is indicated with broken lines. The cells are induced for lysostaphin (Lss) production at $O D_{600}=1$ with $10 \mathrm{ng} / \mathrm{mL}$ nisin. [OD I 10] or [Lss I 10] indicate conditions for growth or lysostaphin production.

lysostaphin was formed when phosphate was omitted (150 mg/L without phosphate versus $220 \mathrm{mg} / \mathrm{L}$ lysostaphin with phosphate).

After these initial experiments, it was decided to set the following basic fermentation conditions: $\mathrm{pH}$ at 7.0, to use $\mathrm{NH}_{4} \mathrm{OH}$ as neutralizing agent, to add both $0.01 \mathrm{~g} / \mathrm{L}$ sodium phosphate $\left(\mathrm{Na}_{2} \mathrm{HPO}_{4}{ }^{*} 2 \mathrm{H}_{2} \mathrm{O}\right)$ and $100 \mu \mathrm{M}$ $\mathrm{ZnSO}_{4}$. To establish a baseline for lysostaphin production and to analyze the effect of phosphate or zinc on lysostaphin production, an induction experiment was carried out. Induction of lysostaphin production was initiated at $\mathrm{OD}_{600}=1.0$ with $10 \mathrm{ng} / \mathrm{mL}$ nisin. Figure 3 shows the basic pattern of growth and induction. After the addition of nisin, product formation begins immediately, and occurs parallel to growth. When lysostaphin production was induced, growth of the culture slowed down considerably about $30 \mathrm{~min}$ after induction. This is accompanied by a steep drop of the viable counts on lactose M17 agar plates of 4 orders of magnitude. However, despite the growth retardation, lysostaphin production was linear for $8 \mathrm{~h}$ before it abruptly ended (Figure 3) [15].

\section{Fermentation temperature}

Overproduction of proteins can trigger stress responses and thus e.g. degradation of the target protein in the cell [23]. One of the strategies employed to prevent or minimize this effect is to lower the fermentation temperature and thereby lower the threshold for the induction of the stress response, and also slow down protein production. Figure 4 shows both growth and lysostaphin production during fermentation at $30^{\circ} \mathrm{C}, 25^{\circ} \mathrm{C}$ and $20^{\circ} \mathrm{C}$. Induction was carried out at a cell density of $\mathrm{OD}_{600}=1(0.3 \mathrm{~g} / \mathrm{L}$ cell dry weight) with $10 \mathrm{ng} / \mathrm{mL}$ nisin. At $25^{\circ} \mathrm{C}$ and $20^{\circ} \mathrm{C}$ growth is, as expected, slower than at $30^{\circ} \mathrm{C}$. Also lysostaphin production is slower and much lower at $20^{\circ} \mathrm{C}$ as compared to $30^{\circ} \mathrm{C}$. However, these experiments also show that the NICE system works at these temperatures; especially at $25^{\circ} \mathrm{C}$ similar yields are obtained as at $30^{\circ} \mathrm{C}$. However, because of the faster production and the slightly 


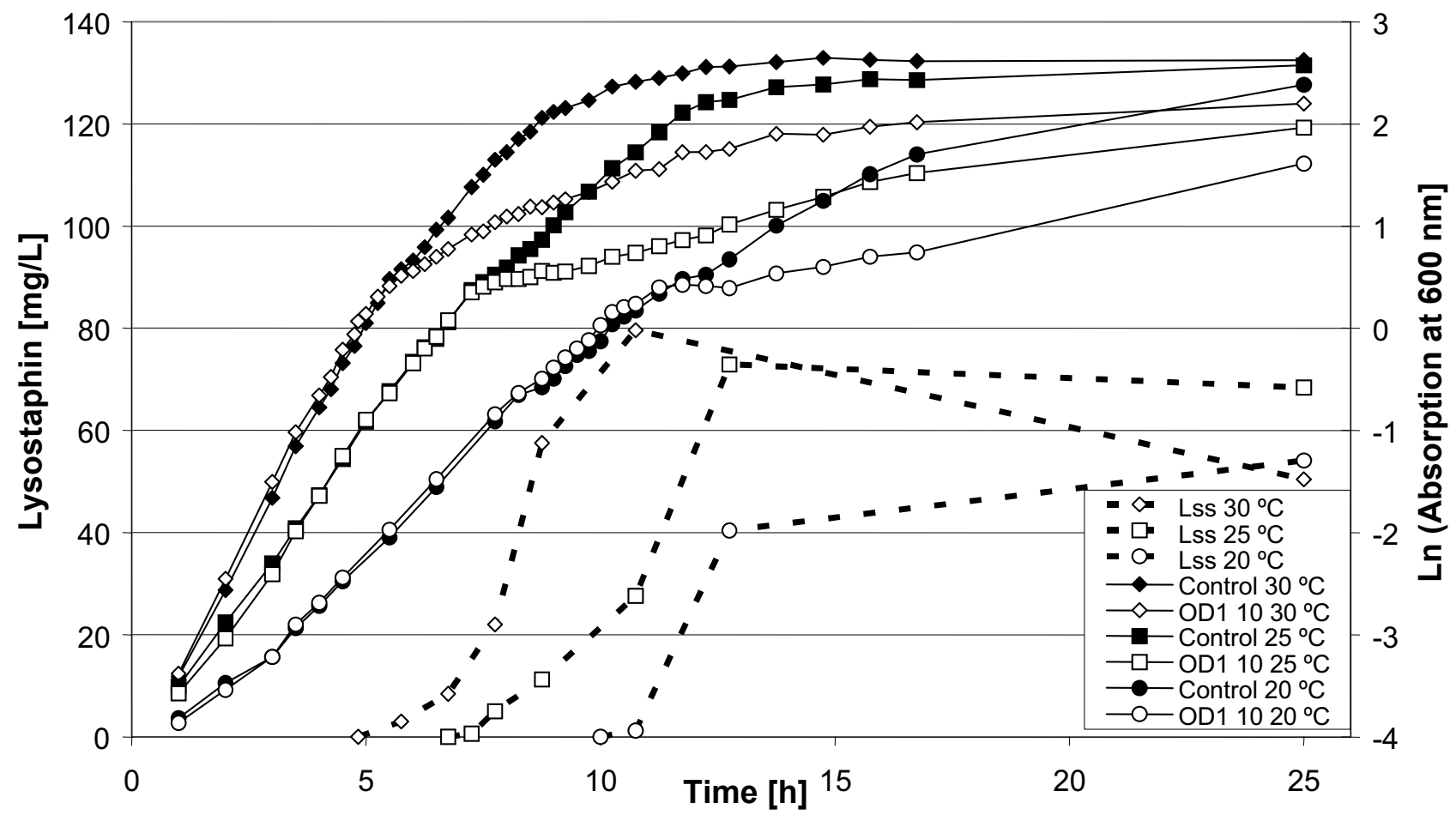

Figure 4

Influence of the temperature on growth, induction and lysostaphin production. Growth of the culture is indicated with continuous lines. Production of lysostaphin is indicated with broken lines. The cells are induced at the different growth temperatures for lysostaphin production at $\mathrm{OD}_{600}=\mathrm{I}$ with $10 \mathrm{ng} / \mathrm{mL}$ nisin. [Lss $30^{\circ} \mathrm{C}$ ], condition for lysostaphin production; [OD I $1030^{\circ} \mathrm{C}$ ], condition for growth.

higher yields, $30^{\circ} \mathrm{C}$ was chosen as fermentation temperature for all subsequent experiments.

\section{Combination of cell density at induction and the amount of added nisin}

If induction could be performed at higher cell densities a higher yield per volume of culture fluid could be expected. Since at higher cell densities more nisin may also be needed for complete induction, these parameters were tested together. Initial experiments showed that induction could be performed at an $\mathrm{OD}_{600}$ of 3 or even 5 . Figure 5 shows an experiment were induction was tested at $\mathrm{OD}_{600}$ values of 1, 5 and 7 (equal to a cell dry weight of $0.3 \mathrm{~g} / \mathrm{L}$, $1.5 \mathrm{~g} / \mathrm{L}$ and $2.1 \mathrm{~g} / \mathrm{L}$, respectively) with nisin concentrations of up to $80 \mathrm{ng} / \mathrm{mL}$. Clearly lysostaphin production can be increased when the culture is induced at higher cell densities. At the same time, more nisin needs to be added for maximum induction. When induction was performed at $\mathrm{OD}_{600}=5,160 \mathrm{mg} / \mathrm{L}$ lysostaphin was formed with 20 $\mathrm{ng} / \mathrm{mL}$ nisin and $220 \mathrm{mg} / \mathrm{L}$ lysostaphin was produced when $40 \mathrm{ng} / \mathrm{mL}$ nisin was used for induction. This means that there was a clear correlation between the cell density at induction and the amount of nisin that is needed for maximal induction. Induction at even higher cell densities, $\mathrm{OD}_{600}=7$ with 40 and $80 \mathrm{ng} / \mathrm{mL}$ nisin, was also tried; however this did not lead to higher lysostaphin yields, indicating that there is a limit in the growth cycle beyond which induction becomes ineffective. Exponential growth without induction continues until about $\mathrm{OD}_{600}=8$, after which growth slows down as the culture slowly approaches the final cell density of about 15 . This is due to the accumulating lactate that increasingly interferes with the energy metabolism of the cell $[24,25]$. The same mechanism also affects and limits the production of the recombinant protein. Induction at a cell density of $\mathrm{OD}_{600}$ $=5$ with $40 \mathrm{ng} / \mathrm{mL}$ nisin resulted in a maximum yield of the recombinant protein.

\section{Addition of extra nutrients}

Although induction was successful at a five times higher cell density than the original induction conditions, we observed only about 2 - 2.5 times more product formation. This could be due to either a shortage in building blocks, i.e. amino acids or a limitation of the 


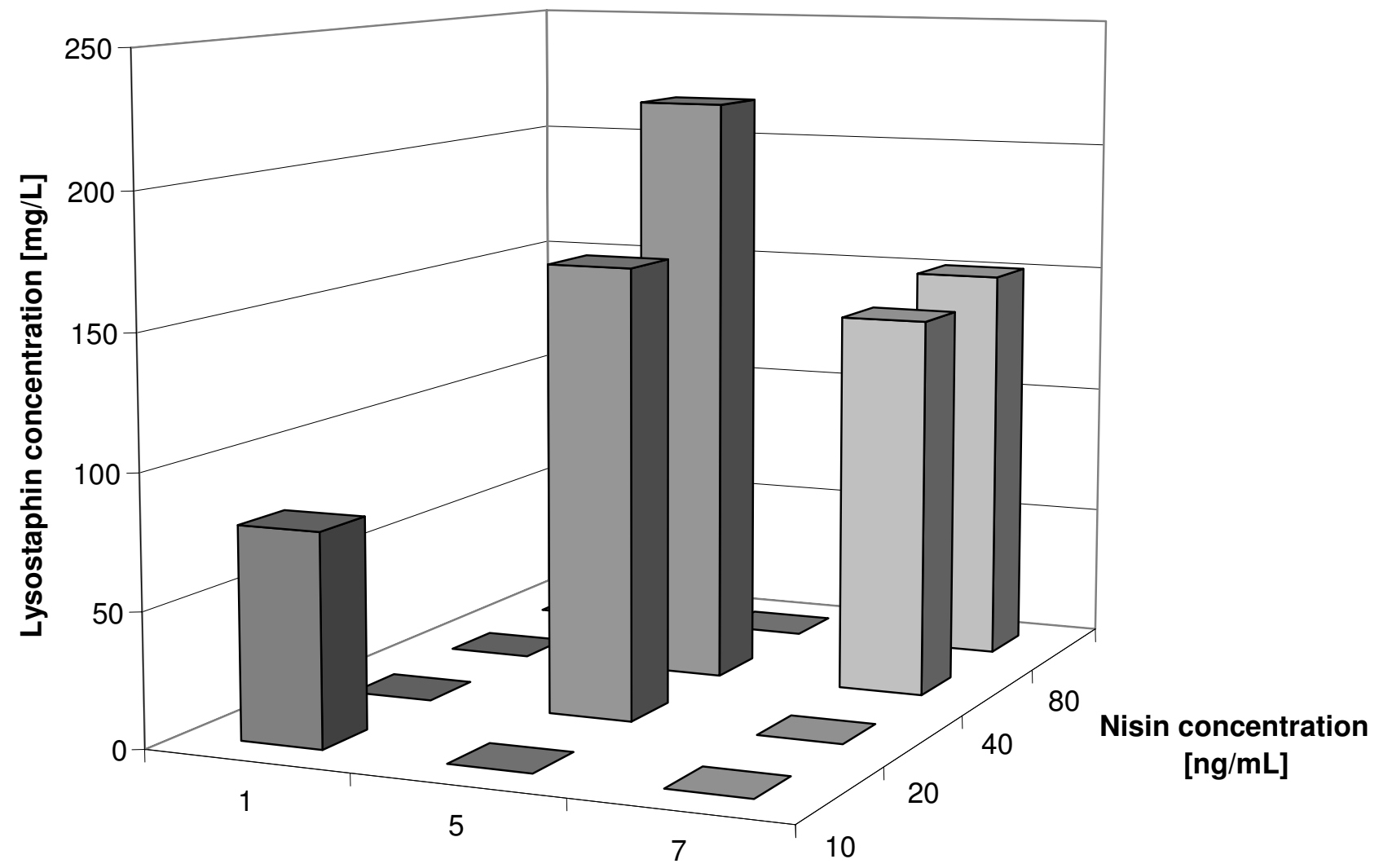

Optical density (OD600) at induction

\section{Figure 5}

Influence of the time point of induction and the amount of added nisin on the amount of produced lysostaphin 8 hours after induction. The time point of induction is indicated as the optical density of the culture $\left[O D_{600}\right]$ at which nisin was added.

energy supply, i.e. the fermentable sugar. Therefore, the next step was to supply more nitrogen and carbohydrate sources. Initial experiments showed that the lysostaphin yield increases when either more yeast extract or more peptone was added and increases even more when both nutrients were increased simultaneously (results not shown). Figure 6 shows a series of fermentations in which the influence of a combination of nitrogen and carbon sources on product formation was investigated. Lysostaphin production was induced at $\mathrm{OD}_{600}=5(1.5 \mathrm{~g} /$ L cell dry weight) with $40 \mathrm{ng} / \mathrm{mL}$ nisin. The addition of extra carbon source, $7 \%$ lactose versus $5 \%$ lactose, did not significantly increase the production of lysostaphin. However, doubling of the carbon source did raise lysostaphin yield from $225 \mathrm{mg} / \mathrm{L}$ to $290 \mathrm{mg} / \mathrm{L}$. An increase in the supply of the nitrogen sources peptone and yeast extract also raised the lysostaphin yield form $225 \mathrm{mg} / \mathrm{L}$ to $290 \mathrm{mg} / \mathrm{L}$.
In a final experiment we used the best medium $(2.5 \%$ peptone, 2\% yeast extract and 7\% lactose) and looked again at the combination of cell density and the amount of nisin for induction (Figure 7). Clearly, either lower or higher cell densities $\left(\mathrm{OD}_{600}=4\right.$ or 7$)$ lead to slower production and lower yields. The same is true for the addition of more nisin $(60 \mathrm{ng} / \mathrm{mL})$, which at that concentration probably has a detrimental effect on the production of lysostaphin.

\section{Summary of the optimization}

The highest production of lysostaphin was observed under the following conditions: the $\mathrm{pH}$ is fixed at 7.0, the temperature is $30^{\circ} \mathrm{C}$, the neutralizing agent is $\mathrm{NH}_{4} \mathrm{OH}$, medium components are $7 \%$ lactose, $2.5 \%$ peptone, $2 \%$ yeast extract, $0.01 \%$ sodium phosphate $\left(\mathrm{Na}_{2} \mathrm{PO}_{4} * 2\right.$ $\left.\mathrm{H}_{2} \mathrm{O}\right), 100 \mu \mathrm{MnSO}_{4^{\prime}} 1 \mathrm{mM} \mathrm{MgSO}_{4}$ and $0.1 \mathrm{mM} \mathrm{MnSO}_{4^{\prime}}$ 


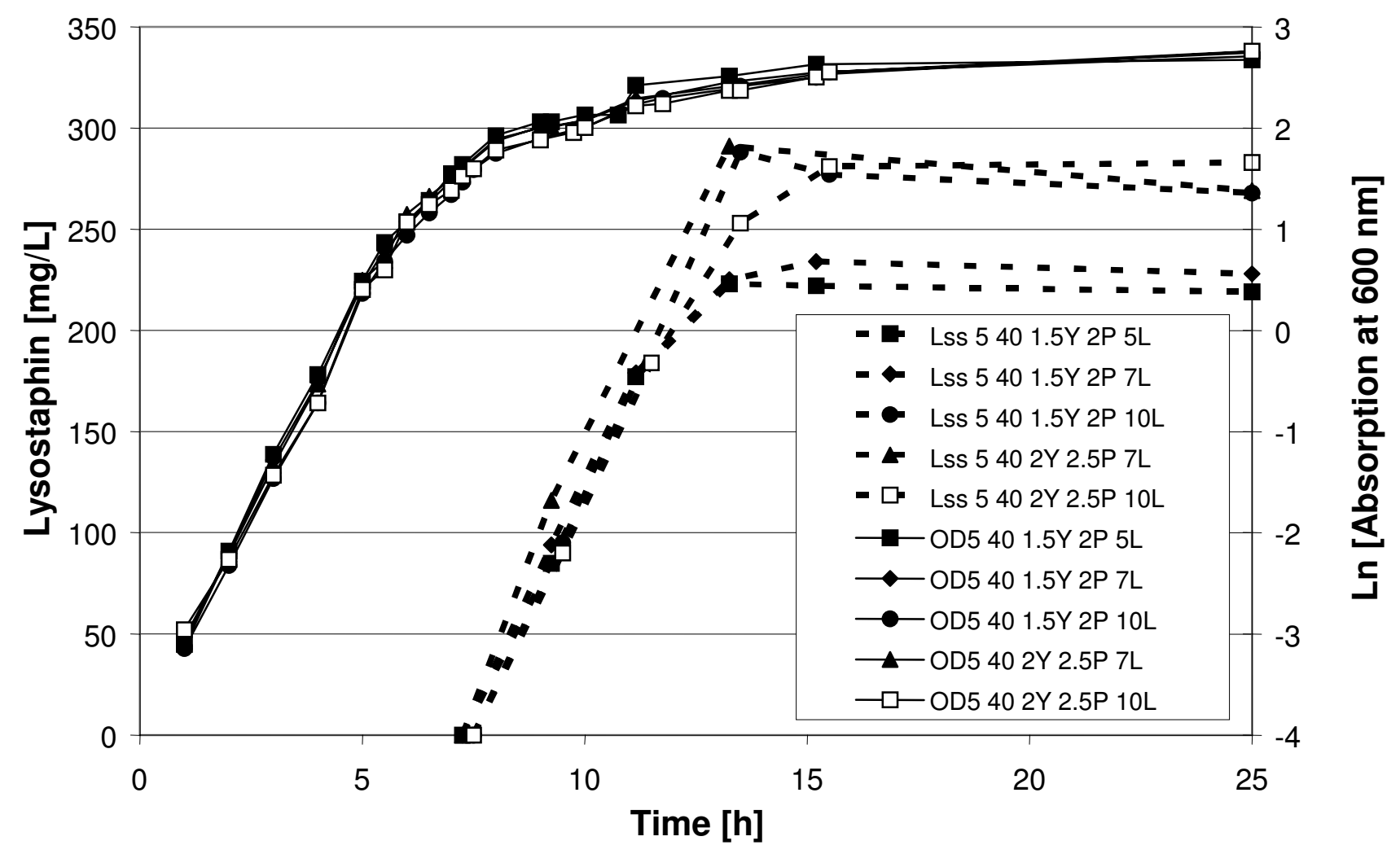

Figure 6

Influence of the medium composition on lysostaphin yield. Growth of the culture is indicated with continuous lines. Production of lysostaphin is indicated with broken lines. Lysostaphin production was induced at $O D_{600}=5$ with $40 \mathrm{ng} / \mathrm{mL} \mathrm{nisin}$. $\mathrm{Y}, \mathrm{P}$, and $\mathrm{L}$ indicate the percentage of yeast extract, peptone and lactose, respectively, used in the culture medium. [Lss 540 I.5Y 2P 5L], conditions for lysostaphin production; [OD 540 I.5Y 2P 5L], conditions for growth.

cells are grown to an $\mathrm{OD}_{600}=5$ and induced with $40 \mathrm{ng} /$ $\mathrm{mL}$ nisin. Lysostaphin production proceeded for 6 to 8 hours and then abruptly stopped. After that time there may be a small decrease of lysostaphin concentration over time. However, this depended on the medium composition and the fermentation conditions (Figures 4,6 and 7).

\section{Discussion}

The nisin-controlled gene expression system NICE is widely used for a multitude of different applications. However, induction of this gene expression system has never been optimized for either laboratory conditions or for industrial-scale applications. In the present publication we show that the yield of the production of a heterologous protein can be increased at least three-fold by careful optimization of the fermentation and induction conditions. A number of general observations have been made:
(I) in a pH controlled culture, the point at which the $\mathrm{pH}$ is fixed and the neutralizing agent influence the general growth and biomass yield of the culture. A neutral $\mathrm{pH}$ and a mild neutralizing agent such as $\mathrm{NH}_{4} \mathrm{OH}$ was beneficial for growth of lactococci.

(II) Nisin induction works over a broad range of temperatures, even at $20^{\circ} \mathrm{C}$. However, there is a clear correlation between the temperature of the fermentation and the speed and yield of the induction. The lower the temperature, the slower was the response to nisin and the lower was the yield of the heterologous protein. For lysostaphin production, a temperature of $30^{\circ} \mathrm{C}$ was found to be the optimum. Figure 4 may give a hint that it is worthwhile to also consider production at a lower temperature. At $25^{\circ} \mathrm{C}$ maximum lysostaphin production was slower and somewhat lower than at $30^{\circ} \mathrm{C}$; however it seemed to be more stable in the cells, as can be seen at the end of the culture. 


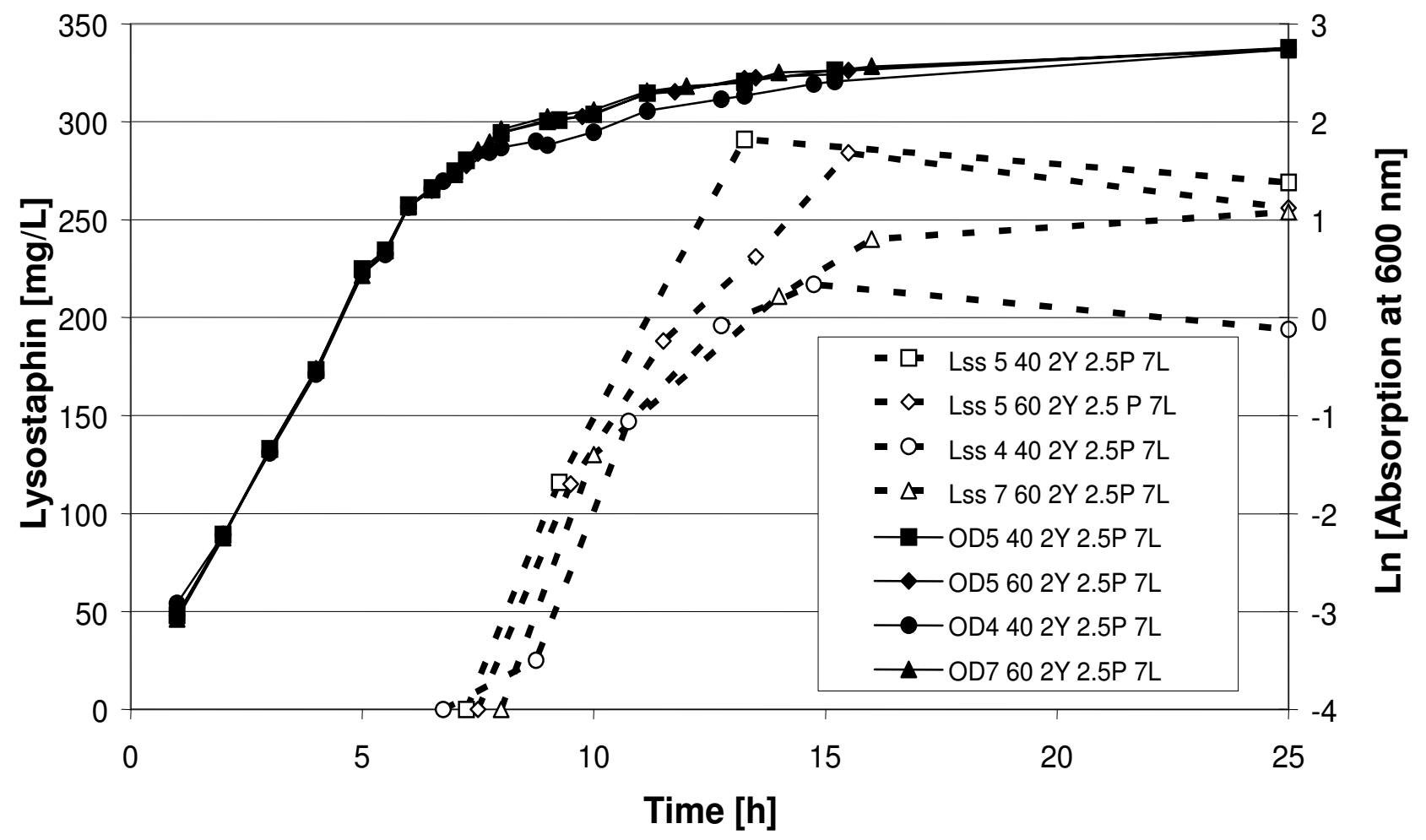

Figure 7

Influence of induction conditions and the medium composition on lysostaphin yields. Growth of the culture is indicated with continuous lines. Production of lysostaphin is indicated with broken lines. The cultures were induced at an $\mathrm{O}_{600}=4$, 5 or 6 with 40 or $60 \mathrm{ng} / \mathrm{mL}$ nisin. $Y, P$, and L indicate the amount in \% of yeast extract, peptone and lactose, respectively, used in the culture medium. [Lss $5402 \mathrm{Y} 2.5 \mathrm{P} 7 \mathrm{~L}$ ], conditions for lysostaphin production; [OD $5402 \mathrm{Y} 2.5 \mathrm{P}$ 7L], conditions for growth.

(III) Addition of extra and specific nutrients may be needed. Lysostaphin is a zinc-containing enzyme. Production of large amounts of active enzyme may be limited by the amount of zinc that is present in the different medium components. Therefore, extra zinc was added.

More generally, phosphate is needed for DNA biosynthesis and the energy metabolism of the cell. There are certain amounts of phosphorus compounds in the yeast extract and in the peptone, but growth at higher cell densities and product formation may require more phosphorus. Initially, little difference was seen after addition of phosphate, however, in an induction experiment at higher cell densities, strongly reduced product formation was observed $(150 \mathrm{mg} / \mathrm{L}$ lysostaphin without extra phosphate versus $220 \mathrm{mg} / \mathrm{L}$ with phosphate). Zinc is an example of specific components that need to be selected and optimized for each target protein individually.
(IV) There is a strong correlation between the medium composition, the cell density of the culture at the moment of induction and the amount of nisin that is added. Induction is a dynamic process and needs growing cells both for the induction to occur and for the subsequent protein production to proceed as fast and as long as possible. In Figure 5 we saw increases in lysostaphin production after both the cell density for induction and the amount of nisin were increased. However, when the induction occurs too late in the growth cycle $\left(\right.$ e.g. $\left.\mathrm{OD}_{600}=7\right)$ no further product increase can be observed, even when more nisin was added. Similarly, if too much nisin is added (see Figure 7) it will become detrimental for product formation. Under the present conditions the maximum yield was reached at an $\mathrm{OD}_{600}$ around 5 with about $40 \mathrm{ng} / \mathrm{mL}$ nisin. These parameters can directly be used for the increased production of any other heterologous protein and as a starting point for further optimization of the respective process. 
(V) As can be seen in Figure 6, lysostaphin production was still limited by the supply of nutrients in the fermentation medium. Addition of higher amounts of peptone, yeast extract and sugar significantly increased the production of lysostaphin. These parameters need to be carefully optimized, since they make up the highest costs of the growth medium.

The present publication outlines the optimization of controlled expression of heterologous genes in L. lactis using the NICE system. Careful optimization of a number of key parameters leads to a considerable increase in the overall yield of the target protein. The current outline gives a framework for this optimization. However, since every protein is different, a number of steps need to be checked and fine-tuned individually.

After the present round of optimization, the model protein lysostaphin could be produced up to $300 \mathrm{mg} / \mathrm{L}$. Since lysostaphin has a growth-inhibiting effect on the host cells, and maybe also on its own production, a higher production capacity of the L. lactis host can be inferred for target proteins that do not have functionally detrimental effects on the host cells. Application of the described optimization to other target proteins will show the actual potential and limits of $L$. lactis for the industrial production of heterologous proteins.

\section{Conclusion}

The nisin-controlled gene expression system NICE of Lactococcus lactis is one of the most widely used Gram-positive gene expression systems. To date, no systematic study has been undertaken to optimize the system for maximum yields, especially for industrial scale applications. The present study shows that by careful optimization of growth, induction and target protein-specific parameters, an at least three-fold increase of the yield can be achieved.

\section{Methods}

\section{Bacterial strains and growth media}

Lactococcus lactis subsp. cremoris NZ3900 [26] carrying plasmid pNZ1710 (plasmid with gene for mature lysostaphin under control of the nisA promoter; [15]) was stored as frozen stock in M17 medium [27] containing $0.5 \%$ lactose as carbon source and plasmid selection agent. The basic fermentation medium contained 5\% lactose (Lactochem, Borculo Domo Ingredients, Zwolle, The Netherlands), $1.0 \%$ yeast extract (Biospringer, MaisonsAlfort, France), 1.5\% soy peptone (Merck, VWR International, Amsterdam, The Netherlands), $1 \mathrm{mM} \mathrm{MgSO}_{4}$ and $0.1 \mathrm{mM} \mathrm{MnSO}_{4}$. All components were dissolved in water and sterilized at $110^{\circ} \mathrm{C}$ for $20 \mathrm{~min}$. Additional components such as $\mathrm{Na}_{2} \mathrm{HPO}_{4}$ and $\mathrm{ZnSO}_{4}$ were filter sterilized and added separately.
Nisin for induction was prepared as follows: $0.04 \%$ nisin powder (Sigma-Aldrich Chemie, Zwijndrecht, The Netherlands) was dissolved in $0.05 \%$ acetic acid and precipitated proteins were removed by centrifugation. Nisin was added for induction as indicated in the Results section.

\section{Fermentations}

The strain was taken from stock and sub-cultured twice before inoculation. 1-L Applicon fermenters were used coupled to an Applicon Biocontroller ADI 1030 (Applicon, Frederiksberg, Denmark) for $\mathrm{pH}$ and temperature control. The $\mathrm{pH}$ of the culture was controlled at the indicated values (see Results) with either $2.5 \mathrm{M} \mathrm{NaOH}$ or $2.5 \mathrm{M} \mathrm{NH}_{4} \mathrm{OH}$. The cell density was measured in samples that were taken at regular intervals, by determining the absorbance at $600 \mathrm{~nm}$ with a path length of $1 \mathrm{~cm}\left[\mathrm{OD}_{600}\right]$. For lysostaphin measurements, cells of appropriate samples were sedimented by centrifugation and stored at $20^{\circ} \mathrm{C}$. After thawing, cell density was adjusted to $\mathrm{OD}_{600}=$ 10 (according to the initial cell density reading) and $1 \mathrm{ml}$ of the cell suspension was mixed with $1 \mathrm{~g}$ glass beads $(0.1$ mm Zirconia/Silica beads from Biospec products, Bartlesville, OK., U.S.A.) in screw-cap Eppendorf tubes. Subsequently, cells were subjected to bead-beating in a FastPrep beadbeater (FP120, QBiogene, Irivne, CA, U.S.A.), adjustment $4,4 \times 30 \mathrm{~s}$. After the beads were allowed to sediment, lysostaphin concentration was determined in the whole cell extract.

\section{Lysostaphin measurement}

Lysostaphin was quantified using SDS-capillary zone electrophoresis (SDS-CZE). The SDS sample buffer was prepared by dissolving in ca. $80 \mathrm{~mL}$ of water $606 \mathrm{mg}$ of tris(hydroxymethyl)aminomethane (Tris), $1.00 \mathrm{~g}$ of sodium dodecylsulphate (SDS) and $37 \mathrm{mg}$ of EDTA. Hydrochloric acid $(0.1 \mathrm{M}, 14.7 \mathrm{~mL})$ was added and the solution was made up to $100 \mathrm{~mL}$. Daily, $25 \mathrm{mg}$ of DTT was added to $10 \mathrm{~mL}$ SDS sample buffer. This solution was used to dissolve cell extract samples (see below).

The SDS-CZE separation was performed using a Beckman Coulter P/ACE MDQ capillary electrophoresis system (CA, U.S.A.), equipped with a UV-detector operating at $214 \mathrm{~nm}$ using a $30 \mathrm{~cm}$ coated capillary and the separation buffer of the Beckman Coulter SDS 14-200 kit. The capillary temperature was set at $20^{\circ} \mathrm{C}$.

Before each analysis, the $30 \mathrm{~cm}$ capillary was rinsed in the reverse direction for $1 \mathrm{~min}$ at $20 \mathrm{psi}$ using $0.1 \mathrm{M} \mathrm{HCl}$ and subsequently for $3 \mathrm{~min}$ at 20 psi with SDS separation buffer. The sample solution was injected for $30 \mathrm{~s}$ at $1 \mathrm{psi}$, followed by forward rinse for $30 \mathrm{~s}$ at $0.5 \mathrm{psi}$ of SDS sample buffer/water (1:1). The separation voltage was ramped in 
$1 \mathrm{~min}$ to $9 \mathrm{kV}$ (ground at detector outlet) and held constant for $18 \mathrm{~min}$.

A standard solution of lysostaphin was prepared as follows. From a solution of a known concentration of lysostaphin (ca. $1 \mathrm{mg} / \mathrm{mL}$ ) $40 \mu \mathrm{L}$ was pipetted into an Eppendorf vial of $0.5 \mathrm{~mL}$ and $120 \mu \mathrm{L}$ of SDS sample buffer was added. The closed vial was incubated for $30 \mathrm{~min}$ at $80^{\circ} \mathrm{C}$ and subsequently rapidly cooled using ice water. From this solution $80 \mu \mathrm{L}$ was transferred to the sample vial (of $0.2 \mathrm{~mL}$ Eppendorf vial).

For the preparation of samples of cell extracts, the same procedure as that for the standard solution of lysostaphin was followed, except that after cooling in ice water the solution was centrifuged for $5 \mathrm{~min}$ at $3000 \mathrm{~g}$ to remove any possible traces of precipitated proteins.

\section{Element analysis}

Analysis of minerals and trace elements in the basic medium was carried out by ICP-AES (Inductively Coupled Plasma - Atomic Emission Spectrometry) using the Vista Axial ICP of Varian (Palo Alto, CA, U.S.A.). The growth medium sample was prepared for ICP by dry-ashing, dissolved in nitric acid and measured against standards of $\mathrm{Ca}, \mathrm{Mg}, \mathrm{Na}, \mathrm{K}, \mathrm{P}, \mathrm{Fe}, \mathrm{Zn}, \mathrm{Mn}$ and $\mathrm{Cu}$.

\section{Authors' contributions}

IM and JM were the initiators and main supervisors of the experiments. $\mathrm{KO}$ developed the CE lysostaphin assay. IM and ES developed the optimization strategy.

\section{Acknowledgements}

We thank Bert van de Bunt and Fedde Kingma for excellent technical assistance. Furthermore, we thank Andy Lees for critical reading of the manuscript.

\section{References}

I. Teuber M: The Genus Lactococcus. In The Genera of Lactic Acid Bacteria Volume 2. Edited by: Wood BJB and Holzapfel WH. London, Glasgow and others, Blackie Academic \& Professional; 1995:173 $-1234$.

2. Konings WN, Kok J, Kuipers OP, Poolman B: Lactic acid bacteria: the bugs of the new millennium. Current Opinion in Microbiology 2000, 3:276-282.

3. Bolotin A, Wincker P, Mauger S, Jaillon O, Malarme K, Weissenbach J, Ehrlich SD, Sorokin A: The complete genome sequence of the lactic acid bacterium Lactococcus lactis ssp. lactis ILI403. Genome Res 200 I, I I:731-753.

4. Bolotin A, Ehrlich SD, Sorokin A: Studies of genomes of dairy bacteria Lactococcus lactis. Sci Aliment 2002, 22:45-53.

5. Guillot A, Gitton C, Anglade P, Mistou MY: Proteomic analysis of lactococcus lactis, a lactic acid bacterium. Proteomics 2003, 3:337-354

6. de Vos WM: Advances in genomics for microbial food fermentations and safety. Current Opinion in Biotechnology 200I, I 2:493-498.

7. de Ruyter PG, Kuipers OP, Beerthuyzen MM, Alen-Boerrigter I, de Vos WM: Functional analysis of promoters in the nisin gene cluster of Lactococcus lactis. Journal of Bacteriology 1996, I 78:3434-3439.
8. Kuipers OP, de Ruyter PGGA, Kleerebezem M, de Vos WM: Quorum sensing-controlled gene expression in lactic acid bacteria. Journal of Biotechnology 1998, 64:I5-21.

9. Kleerebezem M, Quadri LE: Peptide pheromone-dependent regulation of antimicrobial peptide production in Gram-positive bacteria: a case of multicellular behavior. Peptides 200I, 22:1579-1596.

10. Makrides SC: Strategies for achieving high-level expression of genes in Escherichia coli. Microbiological Reviews 1996, 60:512-538.

II. Hannig G, Makrides SC: Strategies for optimizing heterologous protein expression in Escherichia coli. Trends in Biotechnology 1998, I 6:54-60.

12. Platteeuw C, van Alen-Boerrigter I, van Schalkwijk S, de Vos WM: Food-grade cloning and expression system for Lactococcus lactis. Appl Environ Microbiol 1996, 62:1008-1013.

13. Miyoshi A, Poquet I, Azevedo V, Commissaire J, Bermudez-Humaran L, Domakova E, Leloir Y, Oliveira SC, Gruss A, Langella P: Controlled production of stable heterologous proteins in Lactococcus lactis. Appl Environ Microbiol 2002, 68:3 |4I-3|46.

14. Nouaille S, Ribeiro LA, Miyoshi A, Pontes D, Le Loir Y, Oliveira SC, Langella $\mathrm{P}$, Azevedo V: Heterologous protein production and delivery systems for Lactococcus lactis. Genet Mol Res 2003, 2:I02-III.

15. Mierau I, Leij P, Swam I, Blommestein B, Floris E, Mond J, Smid EJ: Industrial-Scale Production and Purification of a Heterologous Protein in Lactococcus lactis using the Nisin-Controlled Gene Expression System NICE: The Case of Lysostaphin. Microbial Cell Factories 2005:submitted.

16. Thumm G, Götz F: Studies on prolysostaphin processing and characterization of the lysostaphin immunity factor (Lif) of Staphylococcus simulans biovar staphylolyticus. Molecular Microbiology 1997, 23: I25 I-1265.

17. von Eiff C, Kokai-Kun JF, Becker K, Peters G: In vitro activity of recombinant lysostaphin against Staphylococcus aureus isolates from anterior nares and blood. Antimicrob Agents Chemother 2003, 47:3613-36I5.

18. Wu JA, Kusuma C, Mond JJ, Kokai-Kun JF: Lysostaphin disrupts Staphylococcus aureus and Staphylococcus epidermidis biofilms on artificial surfaces. Antimicrob Agents Chemother 2003, 47:3407-34I4.

19. Sybesma W, Starrenburg M, Kleerebezem M, Mierau I, de Vos WM, Hugenholtz J: Increased production of folate by metabolic engineering of Lactococcus lactis. Appl Environ Microbiol 2003, 69:3069-3076.

20. Pedersen MB, Koebmann BJ, Jensen PR, Nilsson D: Increasing acidification of nonreplicating Lactococcus lactis delta-thyA mutants by incorporating ATPase activity. Appl Environ Microbiol 2002, 68:5249-5257.

21. Kashket ER: Bioenergetics of lactic acid bacteria: cytoplasmic pH and osmotolerance. FEMS Microbiology Reviews 1987, 46:233-244.

22. Vasiljevic T, Jelen P: Lactose hydrolysis in milk as affected by neutralizers used for the preparation of crude beta-galactosidase extracts from Lactobacillus bulgaricus I I 842. Innovative Food Science and Emerging Technologies 2002, 3: I75-184.

23. Thumm G, Götz F: Studies on prolysostaphin processing and characterization of the lysostaphin immunity factor (Lif) of Staphylococcus simulans biovar Staphylolyticus. Molecular Microbiology 1997, 23: I25I-I 265.

24. Gill RT, DeLisa MP, Valdes J], Bentley WE: Genomic analysis of high-cell-density recombinant Escherichia coli fermentation and "cell conditioning" for improved recombinant protein yield. Biotechnol Bioeng 200I, 72:85-95.

25. ten Brink B, Otto R, Hansen UP, Konings WN: Energy recycling by lactate efflux in growing and nongrowing cells of Streptococcus cremoris. Journal of Bacteriology 1985, 162:383-390.

26. Otto R, Sonnenberg AS, Veldkamp H, Konings WN: Generation of an electrochemical proton gradient in Streptococcus cremoris by lactate efflux. Proc Nat Acad Sci U S A 1980, 77:5502-5506.

27. de Ruyter PG, Kuipers OP, Meijer WC, de Vos WM: Food-grade controlled lysis of Lactococcus lactis for accelerated cheese ripening. Nature Biotechnology 1997, I 5:976-979. 
28. Terzaghi BE, Sandine WE: Improved medium for lactic streptococci and their bacteriophages. Applied Microbiology 1975, 29:807-8I3.

29. Koebmann BJ, Nilsson D, Kuipers OP, Jensen PR: The membranebound $\mathrm{H}(+)$-ATPase complex is essential for growth of Lactococcus lactis. Journal of Bacteriology 2000, 182:4738-4743.

30. Curley P, van Sinderen D: Identification and characterisation of a gene encoding aminoacylase activity from Lactococcus lactis MG I363. FEMS Microbiology Letters 2000, 183:|77-I82.

31. Lopez de Felipe F, Kleerebezem M, de Vos WM, Hugenholtz J: Cofactor engineering: a novel approach to metabolic engineering in Lactococcus lactis by controlled expression of NADH oxidase. Journal of Bacteriology 1998, 180:3804-3808.

32. Looijesteijn PJ, Boels IC, Kleerebezem M, Hugenholtz J: Regulation of exopolysaccharide production by Lactococcus lactis subsp. cremoris by the sugar source. Appl Environ Microbiol 1999, 65:5003-5008.

33. Geoffroy MC, Guyard C, Quatannens B, Pavan S, Lange M, Mercenier $A$ : Use of green fluorescent protein to tag lactic acid bacterium strains under development as live vaccine vectors. Appl Environ Microbiol 2000, 66:383-391.

34. Drouault S, Juste C, Marteau P, Renault P, Corthier G: Oral treatment with Lactococcus lactis expressing Staphylococcus hyicus lipase enhances lipid digestion in pigs with induced pancreatic insufficiency. Appl Environ Microbiol 2002, 68:3166-3168

35. Chatel JM, Langella P, Adel-Patient K, Commissaire J, Wal JM, Corthier $\mathrm{G}$ : Induction of mucosal immune response after intranasal or oral inoculation of mice with Lactococcus lactis producing bovine beta-lactoglobulin. Clin Diag Lab Immunol 200I, 8:545-55I.

36. Kunji ER, Slotboom DJ, Poolman B: Lactococcus lactis as host for overproduction of functional membrane proteins. Biochimica et Biophysica Acta 2003, 16 1 0:97-108.

37. Cibik R, Tailliez P, Langella P, Chapot-Chartier MP: Identification of Mur, an atypical peptidoglycan hydrolase derived from Leuconostoc citreum. Appl Environ Microbiol 200I, 67:858-864.

38. Ribeiro LA, Azevedo VAC, Le Loir Y, Oliveira SC, Dieye Y, Piard JC, Gruss A, Langella P: Production and targeting of the Brucella abortus immunodominant antigen $\mathrm{L7} / \mathrm{LI} 2$ by Lactococcus lactis: a first step towards new live vaccines against brucellosis. Appl Environ Microbiol 200I.

39. Pavan S, Hols P, Delcour J, Geoffroy MC, Grangette C, Kleerebezem $M$, Mercenier A: Adaptation of the nisin-controlled expression system in Lactobacillus plantarum: a tool to study in vivo biological effects. Appl Environ Microbiol 2000, 66:4427-4432.

40. Enouf V, Langella P, Commissaire J, Cohen J, Corthier G: Bovine rotavirus nonstructural protein 4 produced by Lactococcus lactis is antigenic and immunogenic. Appl Environ Microbiol 200I, 67:1423-1428.

41. Bermúdez-Humarán LG, Langella P, Cortes-Perez NG, Gruss A, Tamez-Guerra RS, Oliveira SC, Saucedo-Cardenas O, Montes de Oca-Luna R, Le Loir Y: Intranasal immunization with recombinant Lactococcus lactis secreting murine interleukin- 12 enhances antigen-specific ThI cytokine production. Infect Immun 2003, 7I:I887-1896.

\section{Publish with Bio Med Central and every scientist can read your work free of charge}

"BioMed Central will be the most significant development for disseminating the results of biomedical research in our lifetime. "

Sir Paul Nurse, Cancer Research UK

Your research papers will be:

- available free of charge to the entire biomedical community

- peer reviewed and published immediately upon acceptance

- cited in PubMed and archived on PubMed Central

- yours - you keep the copyright

Submit your manuscript here:

http://www.biomedcentral.com/info/publishing_adv.asp
BiolMedcentral 